\title{
Evaluation and Validation of Equivalent Five-Parameter Model Performance for Photovoltaic Panels Using Only Reference Data
}

\author{
Nouar Aoun1,2,3*, Rachid Chenni' ${ }^{3}$, Boukheit Nahman', Kada Bouchouicha ${ }^{2}$ \\ ${ }^{1}$ Department of Physics, Constantine 1 University, Constantine, Algeria \\ ${ }^{2}$ Research Unit in Renewable Energies in the Saharan Medium, URER/MS, Development Centre of Renewable \\ Energies, Adrar, Algeria \\ ${ }^{3}$ MoDERNa Laboratory, Constantine 1 University, Constantine, Algeria \\ Email: ${ }^{\text {nouar.aoun@gmail.com }}$
}

Received 27 June 2014; revised 1 August 2014; accepted 14 August 2014

Copyright (C) 2014 by authors and Scientific Research Publishing Inc.

This work is licensed under the Creative Commons Attribution International License (CC BY). http://creativecommons.org/licenses/by/4.0/

c) (i) Open Access

\section{Abstract}

This paper presents the modeling of electrical I-V verification of photovoltaic modules using fiveparameter models based on the minimum usage of input data, which are usually provided by manufacturer's datasheet. However, we vary them with a step of $10^{-4}$, the ideality factor $\gamma$ between 0.0 and 4 for each iteration in order to choose the $\gamma$ value, which gives a minimal relative error of the maximum power point. Moreover, when $\gamma$ is known, the other four parameters (i.e., $R_{s}, I_{0}, I_{p h}$ and $R_{s h}$ ) are known. Finally, the effectiveness of this approach is then validated through comparison of the experimental results data under outdoor weather conditions.

\section{Keywords}

Photovoltaic, Five-Parameters, Mono-Crystalline, Relative Error, Ideality Factor

\section{Introduction}

Due to the fossil fuels consumption, the increase of energy demand and the negative effect of pollution on the environment, the photovoltaic solar cell has become one of the promising green and renewable energy solutions. Ge-

\footnotetext{
"Corresponding author.
}

How to cite this paper: Aoun, N., Chenni, R., Nahman, B. and Bouchouicha, K. (2014) Evaluation and Validation of Equivalent Five-Parameter Model Performance for Photovoltaic Panels Using Only Reference Data. Energy and Power Engineering, 6, 235-245. http://dx.doi.org/10.4236/epe.2014.69021 
nerally, the three import points (i.e., maximum power points, short circuit current and open-circuit voltage) are provided on manufacturer datasheets under STC, i.e., $1000 \mathrm{~W} / \mathrm{m}^{2}, 25^{\circ} \mathrm{C}$ and NOCT conditions, i.e., $800 \mathrm{~W} / \mathrm{m}^{2}, 47^{\circ} \mathrm{C}$.

For the modeling of (the) photovoltaic module, the use of equivalent circuits can be seen from the literature [1]-[4]. Reference [5] proposed an equivalent circuit called three-diode model. The third diode is to present the influence of the recombination of carrier and the leakage current. This model is more effective for the poly-silicon cells. The double exponential model [6]-[8] is the most accurate model, which contains seven unknown parameters. In general, this model is more accurate for polycrystalline silicon cells [9].

To make the model easier to be solved, the equivalent circuit can be reduced to a circuit with a one-diode [10]-[14]. In addition, one diode model can be divided into two categories. The first is called the four parameters model [15] [16], where the shunt resistance is neglected and considered as infinite. The second is called the five parameters model [17]-[19], where the shunt resistance is considered as finite. A comparison of five different mathematical one-diode models was studied in detail in [20]. Reference [21] developed an empirical model to produce the current and voltage curve using five located points at the current-voltage curve. However, the method needs empirically coefficients parameters which are typically not available from the manufacturers datasheet. The coefficients are provided by the Sandia National Laboratory [22].

A modified electrical five-parameter-model is presented in the present work. The multi-crystalline PV module is studied by the model under real meteorological conditions in the desert climate.

\section{The Equivalent Circuit of a Solar Cell}

The five-parameter model is one of the famous photovoltaic models in the scientific world. Figure 1 shows the one diode equivalent circuit which contains of a current source $\left(I_{p h}\right)$, a one diode (D), and series/parallel resistances ( $R_{s}$ and $R_{s h}$, respectively).

The characteristic equation model is given by Equation (1).

$$
I=I_{p h}-I_{0}\left[\exp \left(\frac{q\left(V+I R_{s}\right)}{\gamma k T}\right)-1\right]-\frac{V+R_{s} I}{R_{s h}} .
$$

where $I_{p h}$ is the photocurrent (A), $I_{0}$ is the reverse saturation current (A), q is the electron's charge (1.602 $\times$ $\left.10^{-19 \circ} \mathrm{C}\right), \gamma$ the ideality factor, $k=1.38 \times 10^{-23} \mathrm{~J} / \mathrm{K}$ is Boltzmann's constant and $T$ is the temperature of the $p-n$ junction (K), $R_{s}$ the series resistance $(\Omega)$ and $R_{s h}$ the shunt resistance $(\Omega)$.

The five unknown parameters necessities to estimate before to solve Equation (1) are: $\gamma, I_{0}, I_{p h}, R_{s}$, and $R_{s h}$. The ideality factor value $\gamma$ is indicative of the recombination mechanism, it has been observed in the $c$-Si cells. The increasing of solar radiation from 1.6 to 1.1 includes a decrease of the ideality factor in even range [23]. Moreover, at the three important manufacturer points at STC (i.e., short circuit, open circuit tension and maximum power points), Equation (1) can be written as:

Short-circuit current: $I=I_{s c}, V=0$

$$
I_{s c}=I_{p h}-I_{0}\left[\exp \left(\frac{q R_{s} I_{s c}}{\gamma k T}\right)-1\right]-\left(\frac{R_{s} I_{s c}}{R_{s h}}\right)
$$

Open circuit tension: $I=0, V=V_{o c}$

$$
0=I_{p h}-I_{0}\left[\exp \left(\frac{q V_{o c}}{\gamma k T}\right)-1\right]-\left(\frac{V_{o c}}{R_{s h}}\right)
$$

Maximum power point: $I=I_{p}, \quad V=V_{p}$

$$
I_{p}=I_{p h}-I_{0}\left[\exp \left(\frac{q\left(V_{p}+R_{s} I_{p}\right)}{\gamma k T}\right)-1\right]-\left(\frac{V_{p}+R_{s} I_{p}}{R_{s h}}\right)
$$

In [24], the Newton-Raphson method was chosen to calculate the series resistance value and also its convergence time for various initial value of series resistance $R_{s 0}$. In this work, the authors developed this method to find the values of the four unknown parameters $I_{p h}, I_{0}, R_{s h}$ and $R_{s}$ at various ideality factor values $\gamma$. To simplify the calculations, several authors take an ideality factor fixed value. In this paper we vary with a step of 


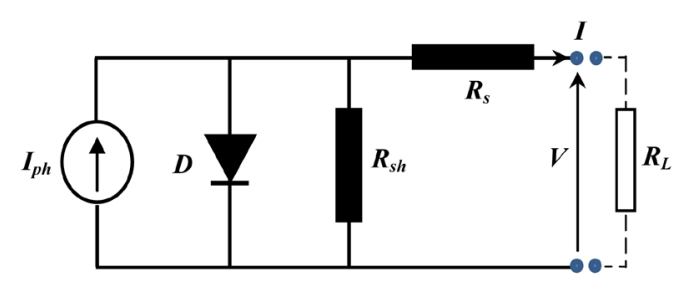

Figure 1. One-diode equivalent circuit for a PV panel.

$10^{-2}$, the ideality factor $\gamma$ between 0 and 3, for each iteration, in order to choose its value which gives a minimal relative error of the maximum power. Reference [24] used the following relationship, Equations (5)-(7) relating to the photo-current $I_{p h}$, the saturation current $I_{0}$, and shunt resistance $R_{s h}$.

$$
\begin{gathered}
I_{p h}=\operatorname{det}^{-1} \cdot\left(V_{o c} I_{s c} A-V_{o c} I_{p} B-V_{p} I_{s c} C\right) \\
I_{0}=\operatorname{det}^{-1} \cdot\left(V_{o c} I_{s c}-V_{o c} I_{p}-V_{p} I_{s c}\right) \\
R_{s h}^{-1}=\operatorname{det}^{-1} \cdot\left[I_{s c} A-I_{p} B-\left(I_{s c}-I_{p}\right) C\right]
\end{gathered}
$$

where:

$$
\begin{gathered}
A=\exp \left(\frac{q\left(V_{p}+R_{s} I_{p}\right)}{\gamma k T}\right)-1 \\
B=\exp \left(\frac{q R_{s} I_{s c}}{\gamma k T}\right)-1 \\
C=\exp \left(\frac{q V_{o c}}{\gamma k T}\right)-1
\end{gathered}
$$

and

$$
\text { det }=\left(V_{o c}-R_{s} I_{s c}\right) \cdot A+\left(-V_{o c}+V_{p}+R_{s} I_{p}\right) \cdot B+\left(-V_{p}+R_{s}\left[I_{s c}-I_{p}\right]\right) \cdot C
$$

The derivative of the maximum power point as expressed in Equation (12):

$$
\left.\frac{\mathrm{d}(I V)}{\mathrm{d} V}\right|_{p}=I_{p}-\left.V_{p} \frac{\mathrm{d} I}{\mathrm{~d} V}\right|_{p}=0
$$

The Equation (1) derivative compared to the tension can be expressed by:

$$
\frac{\mathrm{d} I}{\mathrm{~d} V}=-\left\{R_{s}+\left(\frac{q I_{0}}{\gamma k T} \exp \frac{q\left(V+R_{s} I\right)}{\gamma k T}+\frac{1}{R_{\mathrm{sh}}}\right)^{-1}\right\}^{-1}
$$

We introduce Equation (12) in (13), and then we define a $f_{R_{s}}$ function given by:

$$
f_{R_{s}}=I_{p}-\left(V_{p}-R_{s} I_{p}\right)\left(\frac{q I_{0}}{\gamma k T} \exp \frac{q\left(V_{p}+R_{s} I_{p}\right)}{\gamma k T}+\frac{1}{R_{s h}}\right)
$$

As $I_{0}$ and $R_{s h}$ are depending on $R_{s}$, the $f_{R_{s}}$ function behaves so. For the series resistance $R_{s}$, we suppose that the initial value of the crystalline PV cells is given by the approximate function [25].

$$
R_{s 0}=\frac{V_{o c, \text { ref }}}{I_{s c, \text { ref }}}\left(\alpha_{1} \frac{I_{p, \text { ref }} V_{p, \text { ref }}}{I_{s c, \text { ref }} V_{o c, \text { ref }}}+\alpha_{2} \frac{V_{p, \text { ref }}}{V_{o c, \text { ref }}}+\alpha_{3} \frac{I_{p, \text { ref }}}{I_{s c, \text { ref }}}+\alpha_{4}\right)
$$

with the constants: $\alpha_{i} / i=1: 1: 4$. 


$$
\alpha=\left\{\begin{array}{c}
-5.411 \\
6.45 \\
3.417 \\
-4.422
\end{array}\right\}
$$

We note that Equation (16) is independent of material properties of the solar cell [26].

\section{Effect of Outdoor Condition on the Parameters}

The unknown electrical parameters (i.e., $I_{p h}, I_{0}, \gamma, R_{s}$ and $R_{s h}$ ), was measured under standard test condition $\left(1000 \mathrm{~W} / \mathrm{m}^{2}\right.$ and $\left.25^{\circ} \mathrm{C}\right)$ were rarely found in outdoor climate [27]. Moreover, the dependence of the parameters on the real conditions is described in Equations (17)-(21) [27].

$$
\begin{gathered}
I_{0}=I_{0, \text { ref }}\left(\frac{T_{c}}{T_{\text {ref }}}\right)^{\gamma} \exp \left[\frac{q}{\gamma k}\left(\frac{E_{g}}{T_{\text {ref }}}-\frac{E_{g}}{T_{c}}\right)\right] \\
I_{p h}=\frac{G_{T}}{G_{T, \text { ref }}}\left[I_{p h, \text { ref }}+\mu_{\text {Isc }}\left(T_{c}-T_{c, \text { ref }}\right)\right] \\
n=n_{\text {ref }} \\
R_{s}=R_{s, \text { ref }} \\
R_{s h}=R_{s h \text {,ref }} \frac{G_{T, \text { ref }}}{G_{T}}
\end{gathered}
$$

where $E_{g}$ is the band gap energy.

\subsection{The Cell Temperature}

To predict the performance of PV modules, it is necessary to know the PV cell temperature. In the literature, the modeling of PV cell temperature is obtained by several correlations mathematic models as a function of solar irradiance, ambient temperature and wind speed, etc., [28] [29]. Equation (22) is used to calculate the PV-cell temperature [30].

$$
T_{c}=T_{a}+G_{T} \frac{\text { NOCT }-20}{0.8}
$$

NOCT is the Nominal Operating Cell Temperature which is estimated at $20^{\circ} \mathrm{C}, 0.8 \mathrm{~kW} \cdot \mathrm{m}^{-2}$ and $1 \mathrm{~m} \cdot \mathrm{s}^{-1}$.

\subsection{The Maximum Power Point Current and Voltage}

At any operating condition the maximum power point current and voltage in Equations (23) and (24) can be obtained by iterative method, we used the instrument fsolve in MatLab [31].

$$
\begin{gathered}
I_{p}=I_{p}-I_{0}\left(\exp \left(\frac{q\left(V_{p}+I_{p} R_{s}\right)}{\gamma k T_{c}}\right)-1\right)-\frac{V_{p}+I_{p} R_{s}}{R_{s h}} \\
V_{p}=\frac{I_{p}\left[1+\frac{q I_{0} R_{s}}{\gamma k T_{c}} \exp \left(\frac{q\left(V_{p}+I_{p} R_{s}\right)}{\gamma k T_{c}}\right)+\frac{R_{s}}{R_{s h}}\right]}{\frac{q I_{0}}{\gamma k T_{c}} \exp \left(\frac{q\left(V_{p}+I_{p} R_{s}\right)}{\gamma k T_{c}}\right)+\frac{1}{R_{s h}}}
\end{gathered}
$$

\subsection{Short Circuit Current and Open Circuit Voltage}

Short circuit current and open circuit voltage of the panel at a cell temperature and irradiance other than the ref- 
erence values, can be obtained by simultaneously solving Equations (2) and (3), using fsolve in MatLab/Simulink [22].

\section{Outdoor Tested Photovoltaic Module}

To validate the five parameter model we used an experimental data extracted from specific desert climate environment. The outdoor exposure tests were started on March 21-23, 2013 within the Research Unit in Renewable Energies in the Saharan Medium, Adrar, Algeria. A mono-crystalline silicon solar cell, i.e., S-Energy SMXXXMH1 Series PV module was experimentally selected to perform the characterization and modeling method, Table 1 shows the electrical specifications in the module reference conditions. Table 2 shows the electric parameters calculated by the proposed model.

The measurements of the I-V photovoltaic characteristics were performed with a data acquisition MP-160 I-V curve tracer and a CM11 type Kipp \& Zonenpyranometer (last calibrate February 2011) was used to collect the measurements of meteorological radiation data.

Also, the MP-160 I-V curve tracer was used for determining the important points (i.e., $I_{s c}, V_{o c}, I_{p}$ and $V_{p}$ ) and for tracing the IV curves. The panel temperature was calculated using Equation (22).

The maximum power point for a PV module and the relative error of maximum power point described by the model of this paper according to ideality factor, are illustrated in Figure 2 and Figure 3. The graph represented in Figure 2, reveals that the value of $\gamma=1.58$ we give a maximum power almost equal to that of the manufacturer.

It is noted that the maximum power point of the PV modules studied in this article is calculated according to the manufacturer datasheet by producing the maximum power point current and voltage, i.e., $P=I_{p} \times V_{p}$. This appears clearly in Figure 3, where the relative error is very weak for a value $\gamma$ which corresponds to 1.58.

The manufacturer gives under the test standard conditions $\left(1000 \mathrm{~W} / \mathrm{m}^{2}\right.$ with $\left.25^{\circ} \mathrm{C}\right)$ that the maximum power point equal to $250.2 \mathrm{~W}$, and the simulation gives us $P_{p}=250.151 \mathrm{~W}$. However, the value of the maximum power relative error is $5.63 \%$.

Table 1. The modules nominal electrical specifications.

\begin{tabular}{|c|c|}
\hline \multicolumn{2}{|c|}{ Electrical specifications } \\
\hline$I_{s c}(\mathrm{~A})$ & 9.13 \\
\hline$V_{o c}(\mathrm{~V})$ & 38.7 \\
\hline$I_{p}(\mathrm{~A})$ & 8.34 \\
\hline$V_{p}(\mathrm{~V})$ & 30 \\
\hline$\mu_{V_{\text {oce }}}\left(\% /{ }^{\circ} \mathrm{C}\right)$ & -0.40 \\
\hline$\mu_{I_{x x}}\left(\% /{ }^{\circ} \mathrm{C}\right)$ & 0.05 \\
\hline$N_{s}$ & 60 \\
\hline
\end{tabular}

Table 2. Electrical parameters model for the selected PV module.

\begin{tabular}{cc}
\multicolumn{3}{c}{ Electrical parameters } \\
$\gamma \gamma$ & 1.58 \\
$I_{p h}(\mathrm{~A})$ & 9.1351 \\
$I_{0}(\mathrm{~A})$ & $1.1471 \mathrm{e}-6$ \\
$R_{s}(\Omega)$ & 0.30989 \\
$R_{p}(\Omega)$ & 560.118 \\
\hline
\end{tabular}




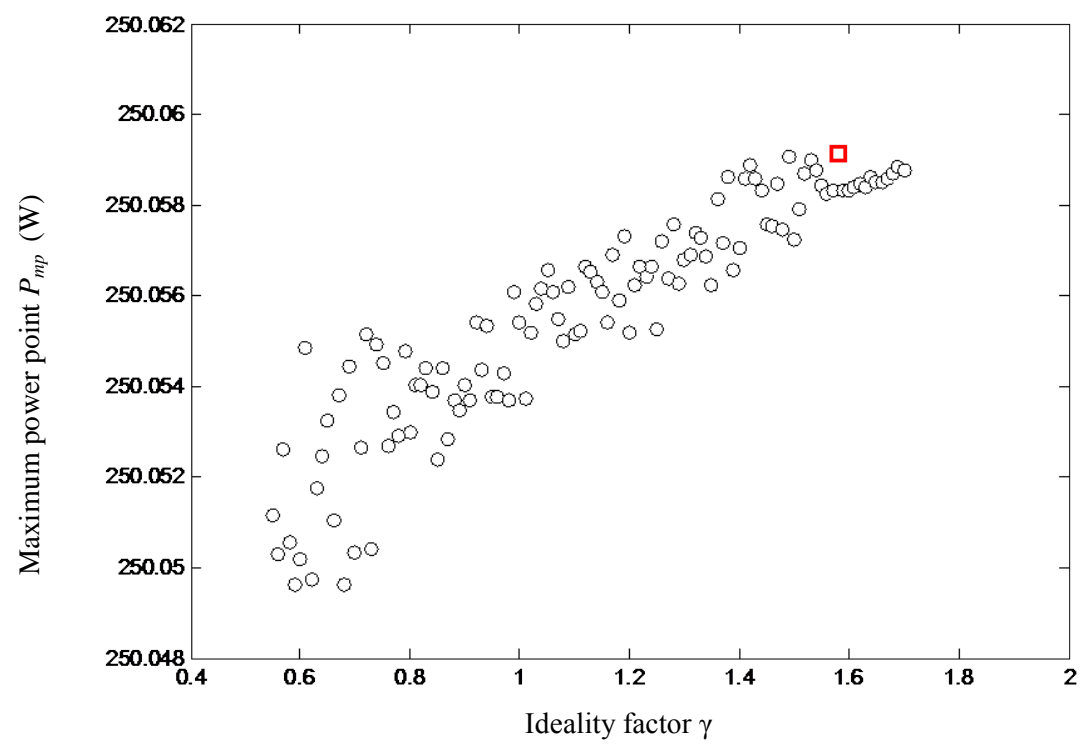

Figure 2. Maximum power point $P_{m p}$ for different accepted values of ideality factor at SRC.

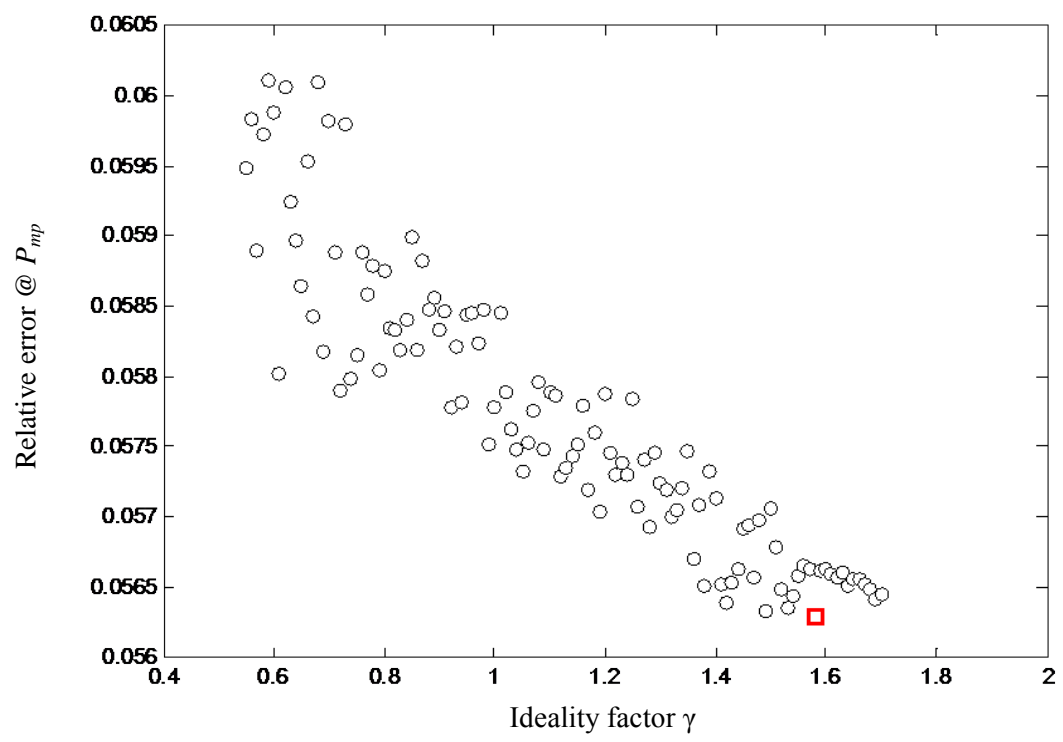

Figure 3. Relative Error for $P_{m p}$ for different accepted values of ideality factor $\gamma$ at SRC.

Figure 4 and Figure 5 indicate the current-voltage and power-voltage of all acceptable values of S-energy PV panel at SRC. It is observed that the majority of the simulated values results are in very good agreement with the three important points: short circuit current, maximum power point and open circuit voltage.

To verify also the model of this paper, it is necessary to observe the curves resulting from the five parameters under varied atmospheric conditions. However, Figure 6 and Figure 7 show the I-V and P-V characteristics of $S$-energy modules in outdoor conditions. Scattered points are the experimental results and solid line is the model results. It can be seen that the I-V and PV curves extracted with the method of this paper is on a good agreement at the current zone with experimental dataset. But at the zone of voltage and maximum power there is a difference between experimental and calculated values. The differences between the experimental data and the calculated values was occurred as a result of limitations in the cell model itself, as well as in the methods used to calculate cell temperature.

For the verification of the model at the three important points (i.e., $I_{s c}, V_{o c}$ and $P_{p}$ ), Figure 8 to Figure 10 show the comparison between the simulated and experimental values of these points during the test days. 


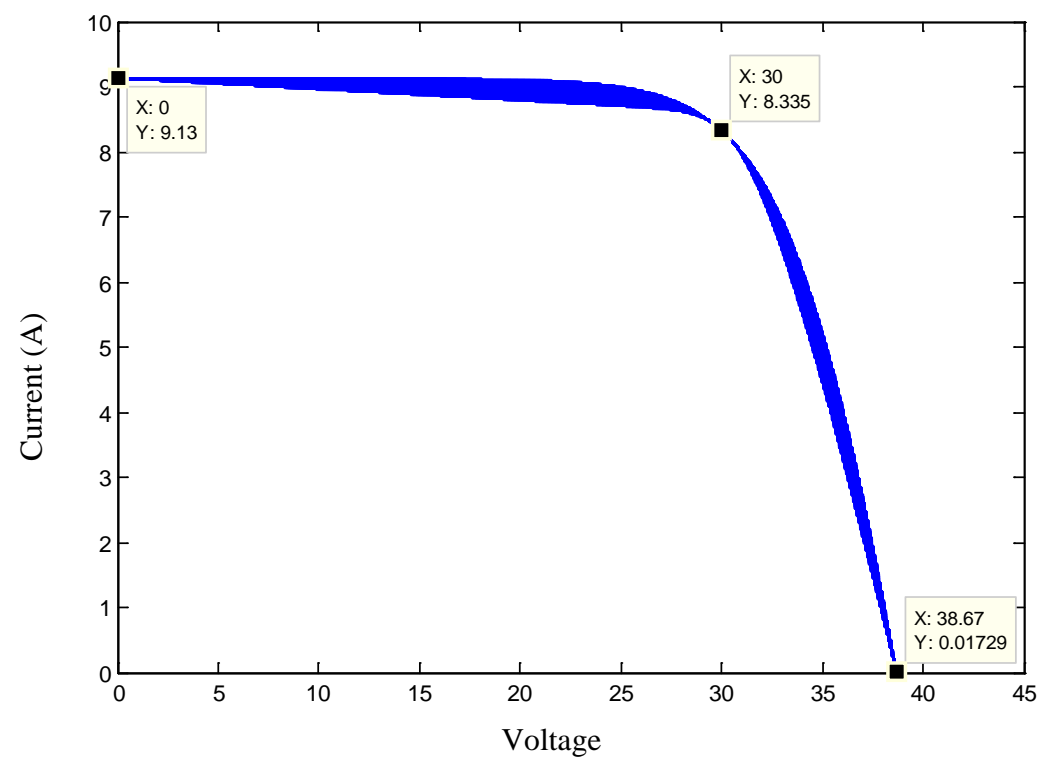

Figure 4. Current-Voltage curves at SRC at different values of ideality factor $\gamma$.

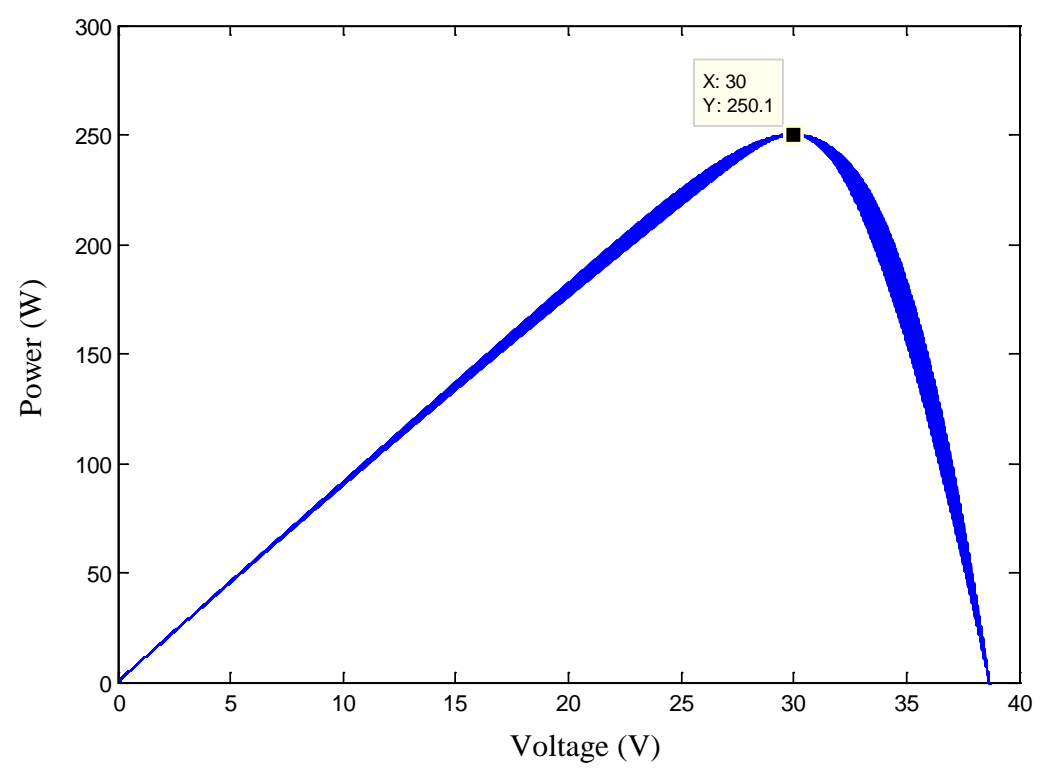

Figure 5. Power-Voltage curves at SRC for different values of ideality factor $\gamma$.

To compare the estimate results with the experimental measurements, the statistical parameters i.e., the root mean square error (RMSE) and the correlation coefficient $\left(R^{2}\right)$ are used. The values of root mean square error RMSE and the correlation coefficient $R^{2}$ of maximum power point are respectively $11.0121 \mathrm{~W}$ and 0.9743 . The correlation coefficient is greater than 0.97, a good agreement between the simulated and measured values is observed. However, the values of root mean square error RMSE and the correlation coefficient $R^{2}$ of short circuit current are respectively $0.6802 \mathrm{~A}$ and 0.9743 . A good agreement between the simulated and measured values is observed.

In Figure 10 we observe a remarkable deviation between simulated and experimental values. However, the values of root mean square error RMSE and the correlation coefficient $R^{2}$ of open circuit voltage are respectively $2.1746 \mathrm{~V}$ and 0.0677 . By far, the open-circuit voltage point $V_{o c}$ is more temperature dependent than the short circuit current $I_{s c} \quad$ [28]. From this, the disparity was also supposed to be mainly caused by the error estimate by the module temperature, which was theoretically measured. 


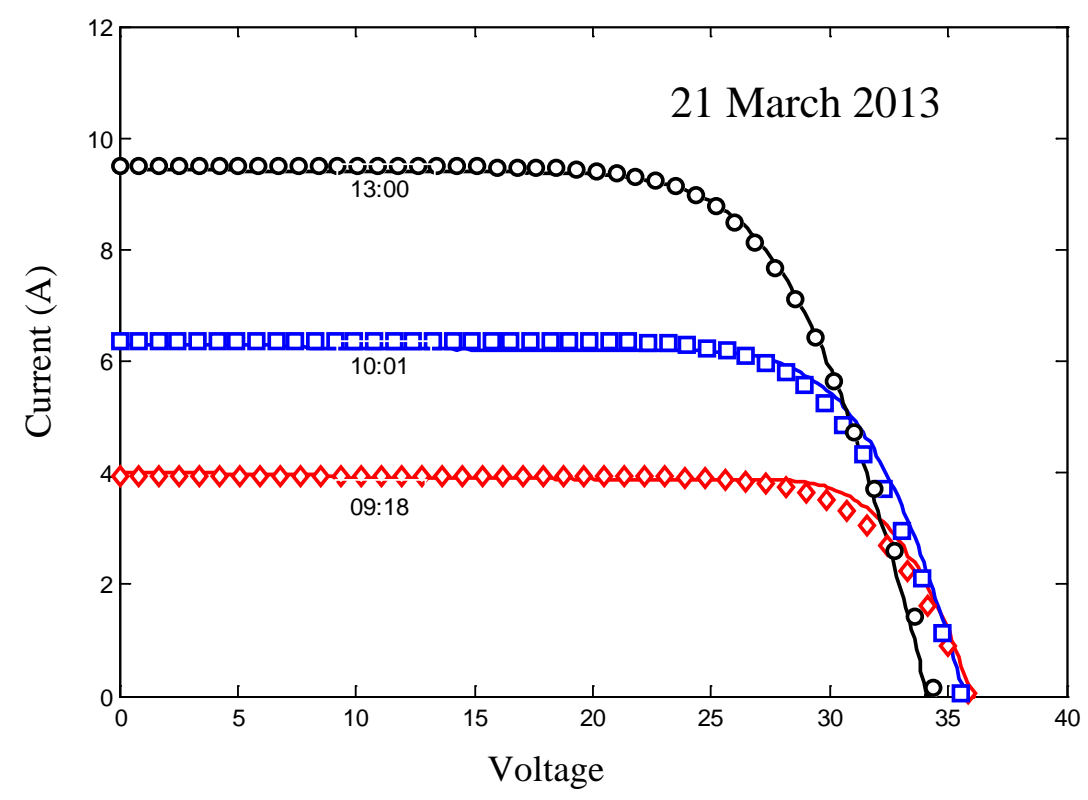

\section{Figure 6. I-V characteristic curves (data from 21/03/2013).}

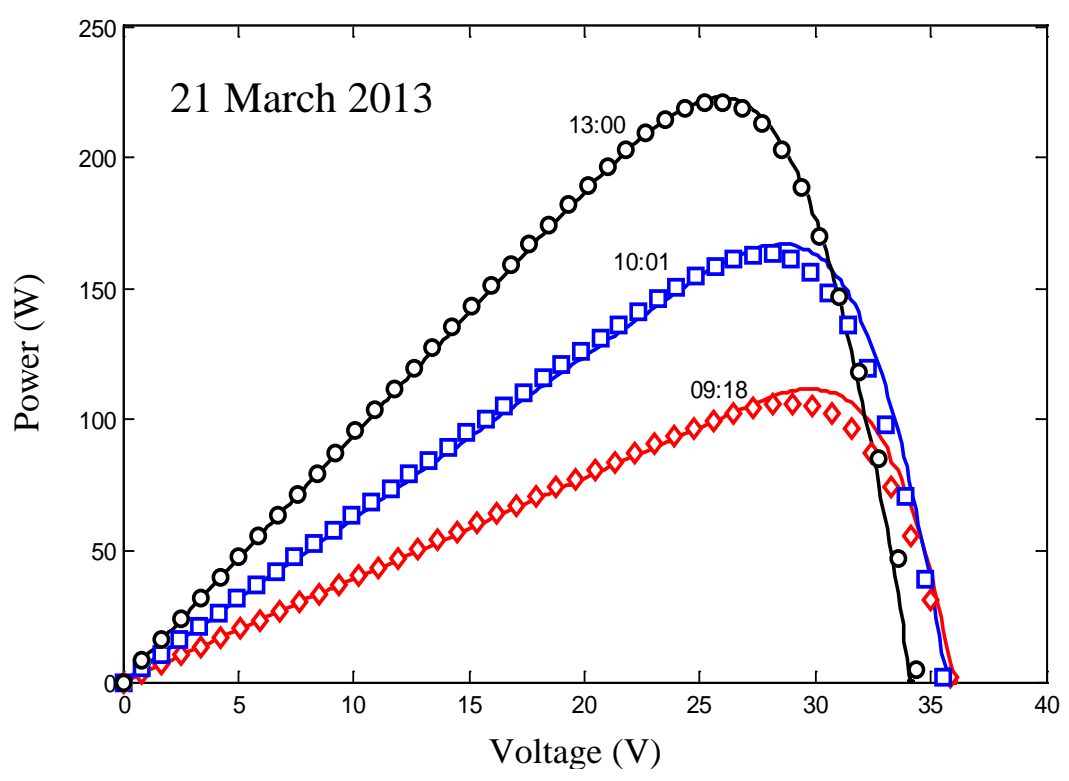

Figure 7. P-V characteristic curves (data from 21/03/2013).

\section{Conclusions}

In this paper, the modeling of the photovoltaic five-parameter-model was proposed. This approach is based on datasheet parameters with a minimum of input information to find and calculate the parameters $\gamma, I_{0}, I_{p h}$, $R_{s}$ and $R_{s h}$ at $\mathrm{STC}\left(25^{\circ} \mathrm{C}, 1000 \mathrm{~W} / \mathrm{m}^{2}\right)$.

The model accuracy was also analyzed through comparison between experimental data and simulation results using mono-crystalline PV-panel in outdoor climate. The plot of I-V and P-V curves extracted by the method of this paper is in a good agreement at the current zone with experimental data, but in the voltage zone and the maximum power zone there is a difference between experimental data and the calculated value. To present the model accuracy more clearly, the maximum power point, short circuit current and open circuit voltage during the three test days were described and evaluated. The agreement between the theoretical estimates and the experi- 


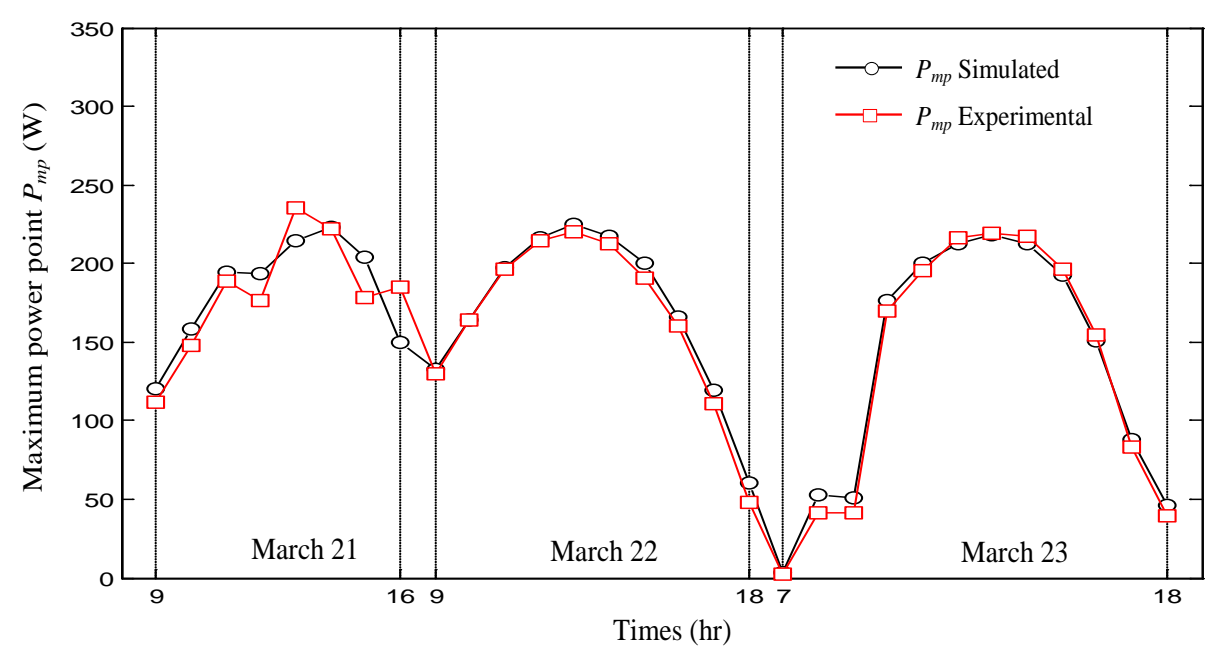

Figure 8. The simulated and experimental values of maximum power point during the three test days.

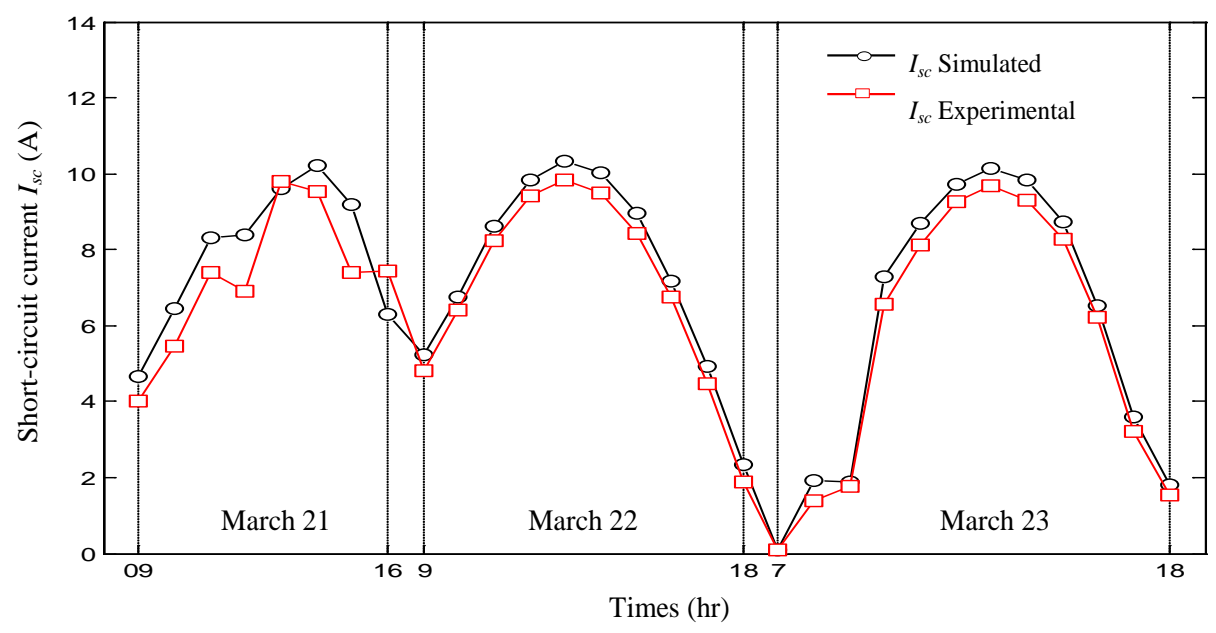

Figure 9. Simulated and experimental values of short-circuit current during the three test days.

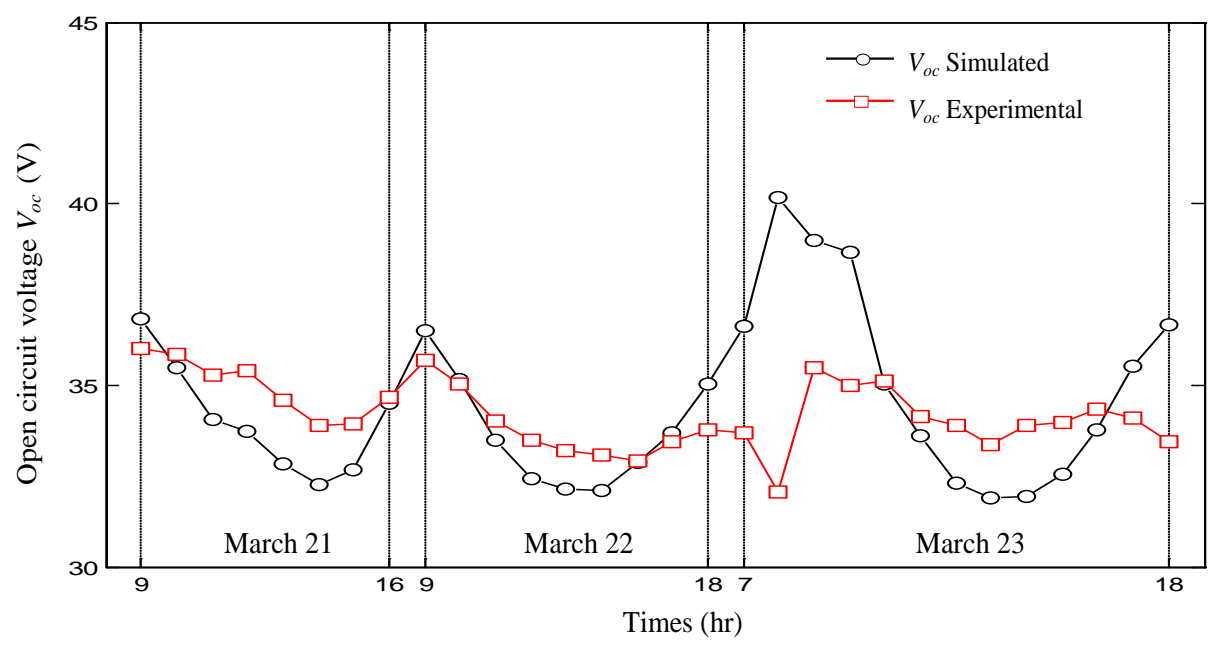

Figure 10. The simulated and experimental values of open circuit voltage during the three test days. 
mental data of the maximum power point and short circuit current is very good in the whole days. The root mean square error RMSE and the correlation coefficient $\left(R^{2}\right)$ of the maximum power point and short circuit current respectively is 0.9743 and 0.9743 , which is very satisfactory. By far, we observe a remarkable deviation between theoretical estimate values and experimental data of the open-circuit voltage point Voc. However, the values of root mean square error RMSE and the correlation coefficient $\mathrm{R}^{2}$ of open circuit voltage are $2.1746 \mathrm{~V}$ and 0.0677 , respectively.

\section{Acknowledgements}

The authors express their gratitude to Mr. Draou Djamel and the team of solar field at the Research Unit in Renewable Energies in the Saharan Medium (URER/MS) for providing the typical electrical parameters and the meteorological radiation data.

\section{References}

[1] Orioli, A. and Di Gangi, A. (2013) A Procedure to Calculate the Five-Parameter Model of Crystalline Silicon Photovoltaic Modules on the Basis of the Tabular Performance Data. Applied Energy, 102, 1160-1177. http://dx.doi.org/10.1016/j.apenergy.2012.06.036

[2] Ding, K., Zhang, J., Bian, X. and Xu, J. (2014) A Simplified Model for Photovoltaic Modules Based on Improved Translation Equations. Solar Energy, 101, 40-52. http://dx.doi.org/10.1016/j.solener.2013.12.016

[3] Karamirad, M., Omid, M., Alimardani, R., Mousazadeh, H. and Heidari, S.N. (2013) ANN Based Simulation and Experimental Verification of Analytical Four- and Five-Parameters Models of PV Modules. Simulation Modelling Practice and Theory, 34, 86-98. http://dx.doi.org/10.1016/j.simpat.2013.02.001

[4] Aoun, N., Chenni, R. and Bouchouicha, K. (2014) Experimental and Validation of Photovoltaic Solar Cell Performance Models in Desert Climate. Applied Mechanics and Materials, 492, 135-142. http://dx.doi.org/10.4028/www.scientific.net/AMM.492.135

[5] Nishioka, K., Sakitani, N., Uraoka, Y. and Fuyuki, T. (2007) Analysis of Multicrystalline Silicon Solar Cells by Modified 3-Diode Equivalent Circuit Model Taking Leakage Current through Periphery into Consideration. Solar Energy Material and Solar Cells, 91, 1222-1227. http://dx.doi.org/10.1016/j.solmat.2007.04.009

[6] Adamo, F., Attivissimo, F., Di Nisio, A. and Spadavecchia, M. (2011) Characterization and Testing of a Tool for Photovoltaic Panel Modeling. IEEE Transactions on Instrumentation Measurement, 60, 1613-1622. http://dx.doi.org/10.1109/TIM.2011.2105051

[7] Veissid, N., Bonnet, D. and Richter, H. (1995) Experimental Investigation of the Double Exponential of a Solar Cell under Illuminated Conditions: Considering the Instrumental Uncertainties in the Current, Voltage and Temperature Values. Solid State Electronics, 38, 1937-1943. http://dx.doi.org/10.1016/0038-1101(95)00017-N

[8] Chan, D.S.H. and Phang, J.C.H. (1987) Analytical Methods for the Extraction of Solar-Cell Single and Double-Diode Model Parameters from I-V Characteristics. IEEE Transaction on Electron Devices, 34, 286-293.

[9] Gow, J.A. and Manning, C.D. (1999) Development of a Photovoltaic Array Model for Use in Power-Electronics Simulation Studies. IEE Proceedings_Electric Power Applications, 146, 193-200. http://dx.doi.org/10.1049/ip-epa:19990116

[10] Ma, T., Yang, H.X. and Lu, L. (2014) Development of a Model to Simulate the Performance Characteristics of Crystalline Silicon Photovoltaic Modules/Strings/Arrays. Solar Energy, 100, 31-41. http://dx.doi.org/10.1016/j.solener.2013.12.003

[11] Villalva, M.G., Gazoli, J.R. and Filho, E.R. (2009) Comprehensive Approach to Modeling and Simulation of Photovoltaic Arrays. IEEE Transactions on Power Electronics, 24, 1198-1208. http://dx.doi.org/10.1109/TPEL.2009.2013862

[12] Boyd, M.T., Klein, S.A., Reindl, D.T. and Dougherty, B.P. (2011) Evaluation and Validation of Equivalent Circuit Photovoltaic Solar Cell Performance Models. Journal of Solar Energy Engineering, 133, Article ID: 021005. http://dx.doi.org/10.1115/1.4003584

[13] Siddiqui, M.U., Arif, A.F.M., Bilton, A.M., Dubowsky, S. and Elshafei, M. (2013) An Improved Electric Circuit Model for Photovoltaic Modules Based on Sensitivity Analysis. Solar Energy, 90, 29-42. http://dx.doi.org/10.1016/j.solener.2012.12.021

[14] Tian, H., Mancilla-David, F., Ellis, K., Muljadi, E. and Jenkins, P. (2012) A Cell-to-Module-to-Array Detailed Model for Photovoltaic Panels. Solar Energy, 86, 2695-2706. http://dx.doi.org/10.1016/j.solener.2012.06.004

[15] Chenni, R., Makhlouf, M., Kerbache, T. and Bouzid, A. (2007) A Detailed Modeling Method for Photovoltaic Cells. 
Energy, 32, 1724-1730. http://dx.doi.org/10.1016/j.energy.2006.12.006

[16] Walker, G. (2001) Evaluating MPPT Converter Topologies Using a Matlab PV Model. Journal of Electrical \& Electronics Engineering Australia, 21, 49-55.

[17] Lo Brano, V. and Ciulla, G. (2013) An Efficient Analytical Approach for Obtaining a Five Parameters Model of Photovoltaic Modules Using Only Reference Data. Applied Energy, 111, 894-903. http://dx.doi.org/10.1016/j.apenergy.2013.06.046

[18] Peng, L., Sun, Y. and Meng, Z. (2014) An Improved Model and Parameters Extraction for Photovoltaic Cells Using Only Three State Points at Standard Test Condition. Journal of Power Sources, 248, 621-631. http://dx.doi.org/10.1016/j.jpowsour.2013.07.058

[19] Lo Brano, V., Orioli, A., Ciulla, G. and Di Gangi, A. (2010) An Improved Five-Parameter Model for Photovoltaic Modules. Solar Energy Materials \& Solar Cells, 94, 1358-1370. http://dx.doi.org/10.1016/j.solmat.2010.04.003

[20] Ciulla, G., Lo Brano, V., Di Dio, V. and Cipriani, G. (2014) A Comparison of Different One-Diode Models for the Representation of $I-V$ Characteristic of a PV Cell. Renewable and Sustainable Energy Reviews, 32, 684-696. http://dx.doi.org/10.1016/j.rser.2014.01.027

[21] King, D., Boyson, W. and Kratochvill, J. (2004) Photovoltaic Array Performance Model. SAND2004-3535, Sandia National Laboratories, Albuquerque.

[22] De Soto, W., Klein, S.A. and Beckman, W.A. (2006) Improvement and Validation of a Model for Photovoltaic Array Performance. Solar Energy, 80, 78-88. http://dx.doi.org/10.1016/j.solener.2005.06.010

[23] de Blas, M.A., Torres, J.L., Prieto, E. and García, A. (2002) Selecting a Suitable Model for Characterizing Photovoltaic Devices. Renewable Energy, 25, 371-380. http://dx.doi.org/10.1016/S0960-1481(01)00056-8

[24] Mustapha, B. (2006) Modélisation et Simulation d’un Système de Pompage Photovoltaïqu. Master's Thesis, Oran University, Algeria.

[25] Wagner, A. (2000) Peak-Power and Internal Series Resistance Measurement under Natural Ambient Conditions. Proceedings of EuroSun 2000, Copenhagen, 19-22 June 2000, 1-7.

[26] Benghanem, M. (2009) Low Cost Management for Photovoltaic Systems in Isolated Site with New IV Characterization Model Proposed. Energy Conversion and Management, 50, 748-755. http://dx.doi.org/10.1016/j.enconman.2008.09.048

[27] Attivissimo, F., Adamo, F., Carullo, A., Lanzolla, A.M.L., Spertino, F. and Vallan, A. (2013) On the Performance of the Double-Diode Model in Estimating the Maximum Power Point for Different Photovoltaic Technologies. Measurement, 46, 3549-3559. http://dx.doi.org/10.1016/j.measurement.2013.06.032

[28] Skoplaki, E., Boudouvis, A.G. and Palyvos, J.A. (2008) A Simple Correlation for the Operating Temperature of Photovoltaic Module of Arbitrary Mounting. Solar Energy Materials \& Solar Cells, 92, 1393-1402. http://dx.doi.org/10.1016/j.solmat.2008.05.016

[29] Topic, M., Brecl, K. and Sites, J. (2007) Effective Efficiency of PV Modules under Field Conditions. Progress in Photovoltaics: Research and Applications, 15, 19-26. http://dx.doi.org/10.1002/pip.717

[30] Luque, A. and Hegedus, S. (2003) Handbook of Photovoltaic Science and Engineering. John Wiley \& Sons Ltd., Chichester. http://dx.doi.org/10.1002/0470014008

[31] Quarteroni, A., Saleri, F. and Gervasio, P. (2010) Calcul Scientifique Cours, Exercices Corrigés et Illustrations en Matlab et Octave. 2nd Edition, Springer-Verlag, Italia. 
Scientific Research Publishing (SCIRP) is one of the largest Open Access journal publishers. It is currently publishing more than 200 open access, online, peer-reviewed journals covering a wide range of academic disciplines. SCIRP serves the worldwide academic communities and contributes to the progress and application of science with its publication.

Other selected journals from SCIRP are listed as below. Submit your manuscript to us via either submit@scirp.org or Online Submission Portal.
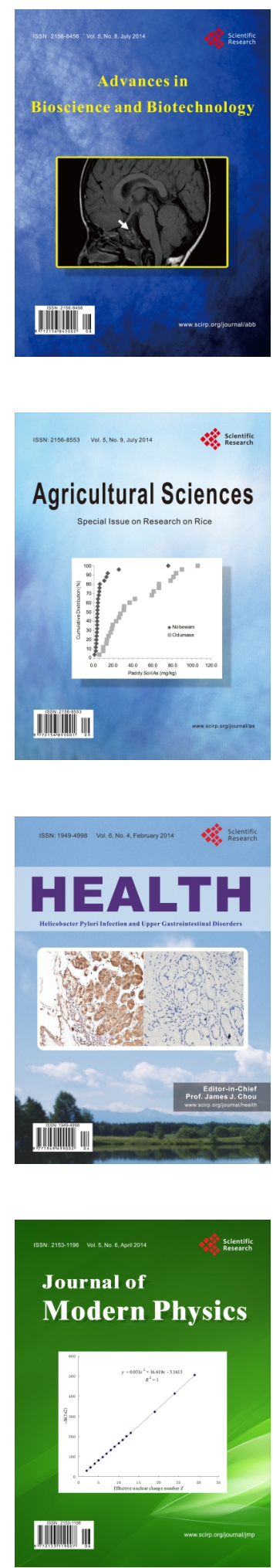
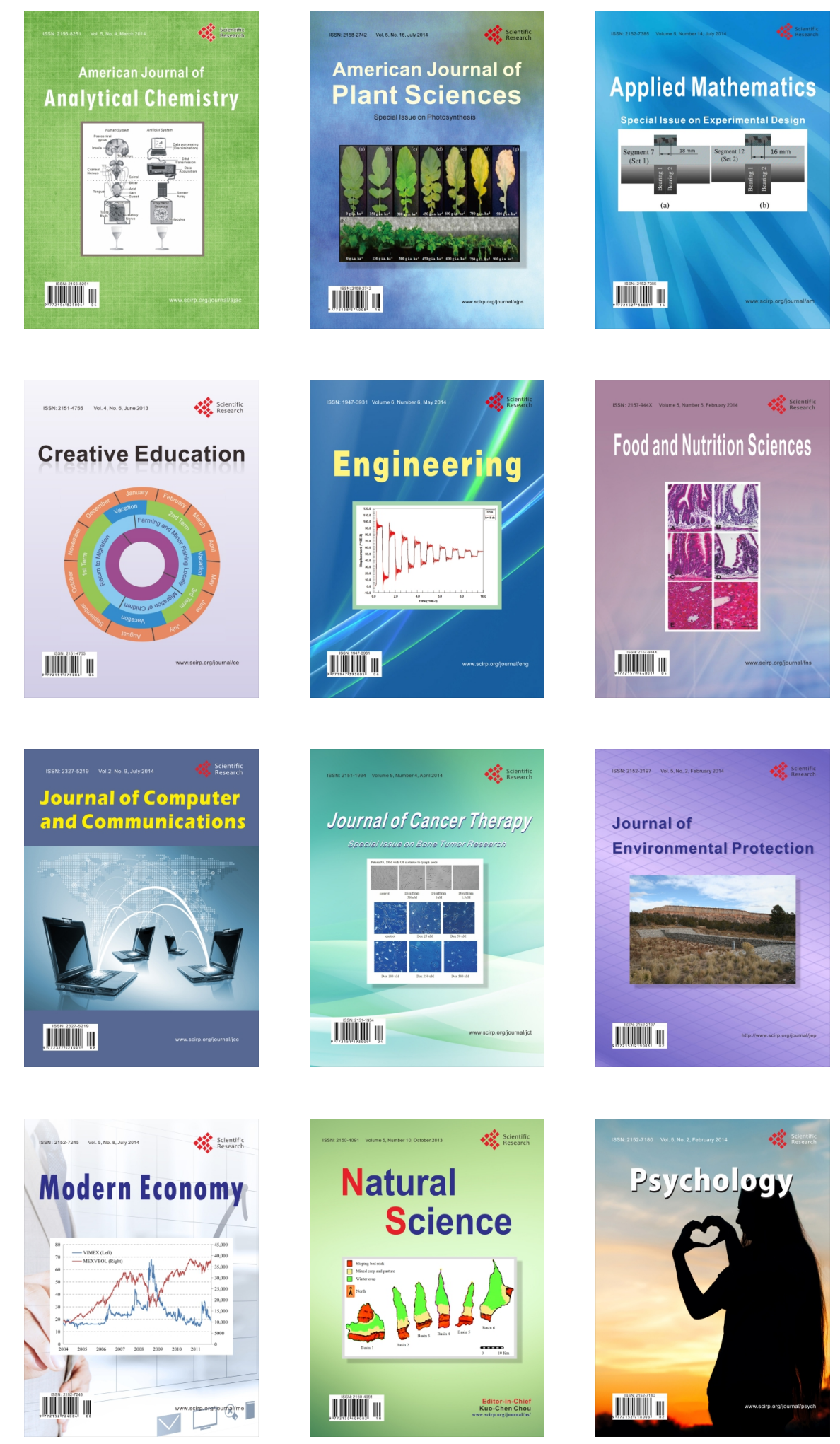